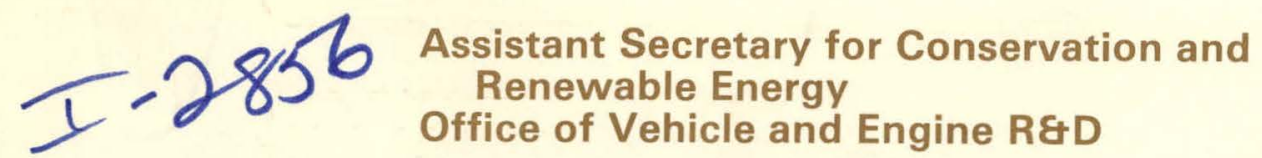 \\ Office of Vehicle and Engine R\&D \\ MASTER
}

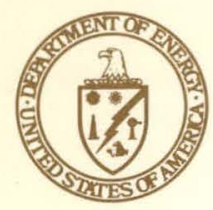

\section{Third Annual Report to Congress on the Automotive Technology Development Program} \section{DO NOT MICROFILM
COVER}

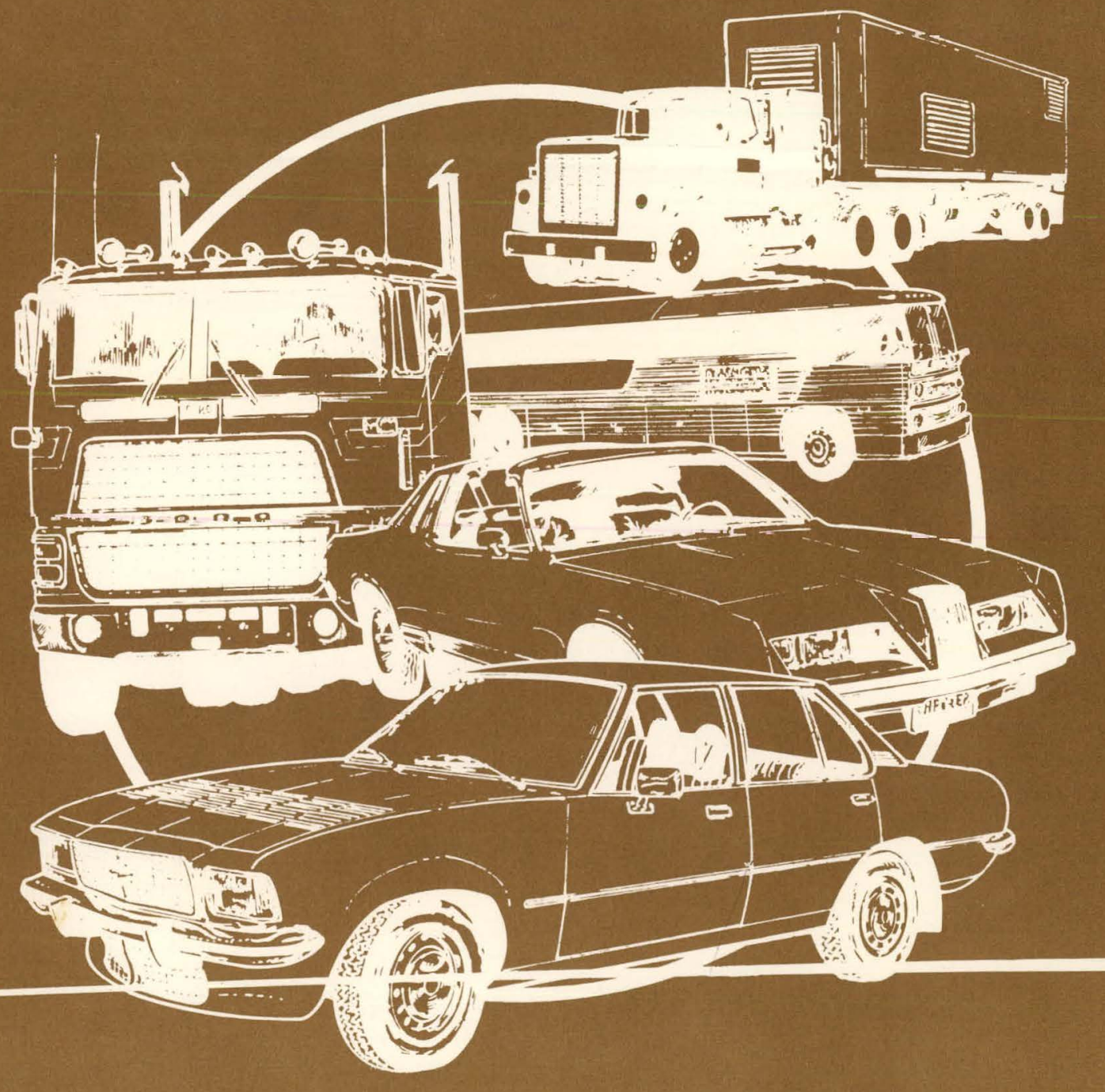




\section{DISCLAIMER}

This report was prepared as an account of work sponsored by an agency of the United States Government. Neither the United States Government nor any agency Thereof, nor any of their employees, makes any warranty, express or implied, or assumes any legal liability or responsibility for the accuracy, completeness, or usefulness of any information, apparatus, product, or process disclosed, or represents that its use would not infringe privately owned rights. Reference herein to any specific commercial product, process, or service by trade name, trademark, manufacturer, or otherwise does not necessarily constitute or imply its endorsement, recommendation, or favoring by the United States Government or any agency thereof. The views and opinions of authors expressed herein do not necessarily state or reflect those of the United States Government or any agency thereof. 


\section{DISCLAIMER}

Portions of this document may be illegible in electronic image products. Images are produced from the best available original document. 
This report has been reproduced directly from the best available copy.

Available from the National Technical Information Service, U. S. Department of Commerce, Springfield, Virginia 22161.

Price: Printed Copy A01

Microfiche A01

Codes are used for pricing all publications. The code is determined by the number of pages in the publication. Information pertaining to the pricing codes can be found in the current issues of the following publications, which are generally available in most libraries: Energy Research Abstracts, (ERA); Government Reports Announcements and Index (GRA and I); Scientific and Technical Abstract Reports (STAR); and publication, NTIS-PR-360 available from (NTIS) at the above address. 
Assistant Secretary for Conservation and

Washington, D.C. 20585

\section{Third Annual Report to Congress on the Automotive Technology Development Program}

$\mathrm{DOE} / \mathrm{CE}--0027$

DE82 013628

NOTE: This report, which is Annex No. 2 of the DOE Annual Report to Congress, is required by Section 310(a) of the Automotive Propulsion Research and Development Act of 1978 (Title III of Public Law 95-238). 


\section{Table of Contents}

Page

PREFACE .

EXECUTIVE SUMMARY $\ldots \ldots \ldots \ldots \ldots \ldots \ldots \ldots \ldots \ldots \ldots \ldots \ldots \ldots \ldots \ldots \ldots \ldots \ldots \ldots \ldots \ldots$

1. INTRODUCTION AND OVERVIEW $\ldots \ldots \ldots \ldots \ldots \ldots \ldots \ldots \ldots \ldots \ldots \ldots \ldots \ldots \ldots \ldots \ldots \ldots$

2. STATUS OF CONVENTIONAL POWERTRAIN TECHNOLOGY $\ldots \ldots \ldots \ldots \ldots \ldots \ldots \ldots \ldots$

3. AUTOMOTIVE TECHNOLOGY DEVELOPMENT PROGRAM $\ldots \ldots \ldots \ldots \ldots \ldots \ldots \ldots \ldots$

3.1. Project Requirements and Objectives......................... 5

3.2. Advanced Gas Turbine Engine Systems Development Project ............ 5

3.3. Advanced Stirling Engine Systems Development Project .............. 8

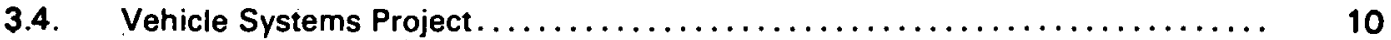

4. MANAGEMENT PLAN AND POLICY TRANSITION $\ldots \ldots \ldots \ldots \ldots \ldots \ldots \ldots \ldots \ldots \ldots \ldots \ldots \ldots$

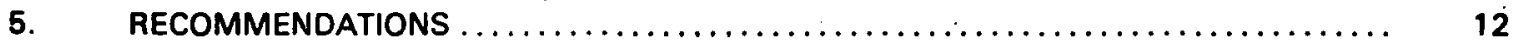

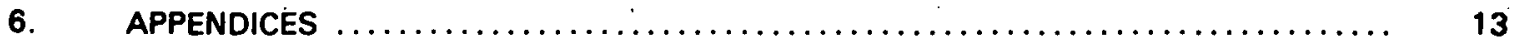

6.1. Appendix A - Procurement Summary-Advanced Gas Turbine Engine Systems Development Project ................................... 13

6.2. Appendix B - Procurement Summary-Advanced Stirling Engine Systems

Development Project ................................ 14

6.3. Appendix C - Procurement Summary -Vehicle Systems Project . .......... 15

6.4. Appendix D - Certification of New R\&D Contracts . . . . . . . . . . . . . . 16 


\section{Preface}

This is the Third Annual Report to Congress on the implementation of the Automotive Propulsion Research and Development Act of 1978 (Title III of Public Law 95-238). It is intended to fulfill the reporting requirements of Sections 310(a) and 304(f), and, in part, is based on work currently in progress. In addition, it serves as a communication link between the Department of Energy's Automotive Technology Development Program and all of the interests involved in the Program.

Specific requirements of Sections 310(a) and 304(f) of Title III of Public Law 95-238 that are addressed in this report are:

Section

310(a), (1)

310(a), (2)

310(a), (3)

310(a), (4)

310(a), (5)

$304(t),(4)$
TItle III Requirement

Current comprehensive program definition for implementing Title III

Evaluation of the state of automobile propulsion system research and development in the United States

Number and amount of contracts and grants made under Title III

Analysis of the progress made in developing advanced automobile propulsion system technology

Suggestions for improvements in advanced automobile propulsion system research and development, including recommendations for legislation.

Discussion of how each research and development contract, grant, or project funded under the authority of this Act satisfies the requirement of this subsection.
Section of

Thlrd Annual

Report to Congress

Executive Summary and Section 3

Sections 2 and 3

Section 6

Executive Summary and Section 3

Section 5

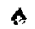

Appendix D 


\section{Executive Summary}

Introduction

On February 25, 1978 the U.S. Congress acted to reduce this Nation's dependence on foreign petroleum by passing the Automotive Propulsion Research and Development Act of 1978. The Act provides for expanded research and development (R\&D) of advanced automobile propulsion system technology to achieve improved fuel economy and multifuel capability. A specific goal is the development of advanced automotive propulsion systems within five years, or within the shortest practicable time consistent with appropriate R\&D techniques. The Act requires that activities conducted under its sponsorship supplement, but neither supplant nor duplicate, private sector efforts.

The Federal approach to transportation energy conservation has now been refocused to make greater use of market forces. Decontrol of crude oil has removed the subsidy to oil usage and will allow transportation conservation to reach its true potential. This stimulus is expected to further increase the demand for small, fuel-efficient cars, therebycausing manufacturers to adjust their production to meet this demand. In this new, healthier environment for conservation, it is possible to shift the Department of Energy's (DOE's) transportation conservation programs away from costly near-term development, demonstration, and commercialization activities, since these activities will be undertaken by the private sector in response to normal market forces. The DOE transportation program will continue to support long-term, high-risk, but potentially high-payoff, $R \& D$ on promising conservation technologies that are unlikely to be undertaken by the private sector alone. These investigations will be pursued with as much guidance and cooperation from industry as can be enlisted.

\section{Policy Transition}

Research, development, and demonstration efforts are now under way to advance the development and accelerate industry acceptance of energyefficient and socially acceptable advanced propulsion systems for highway use. As fuel prices rise, an increased stimulus is present for the U.S. auto industry to continue the production of increasingly efficient automobiles, trucks, and buses, and to incorporate propulsion systems of advanced design and sophistication. However, the move to revolutionary technologies is of sufficient risk and long-term payback to warrant a supplementary Federal activity in supportive technology. Recognizing these recent trends in the industry, the FY 1982 Vehicle Propulsion activity is designed to underwrite, in the most costeffective manner, many of these high-risk activities.

The Vehicle Propulsion Technology Development Program will move from engine development type programs and concentrate its activities in more generic forms of technology in two major areas in FY 1982: (1) technologies related to advancing the state of technology in automotive propulsion systems, and (2) technologies related to improving energy efficiency in truck and bus systems.

\section{Program Implementation and Management}

The Office of Vehicle and Engine R\&D of the DOE is responsible for implementation of the Act's requirements. As Program Manager, DOE formulates, justifies, and manages the automotive R\&D programs; interacts with industry, universities, and government laboratories; and coordinates with other government agencies. Additionally, DOE works closely with the National Aeronautics and Space Administration (NASA) under an Interagency Agreement and a Memorandum of Understanding.

The Lewis Research Center (LeRC) of NASA is the Technical Project Manager and is responsible for accomplishing project objectives, developing detailed project plans, integrating technology disciplines, conducting procurement, interacting with auto industry and university technologies, and solving contractual and technical problems.

The Program is conducted through contracts and grants with industry, universities, and government laboratories. Responsibilities are.specified so that the strengths of each of these organizations are integrated into the Program.

The Advanced Gas Turbine Engine Systems Development Project is designed to culminate in dynamometer tests of critical gas turbine components and systems. These tests are intended to validate component durability and allow assessment of engine performance against the program objectives. Supporting Research and Technology and Early Technology Application activities are included in the project to provide technological options for the reduction of developmental risks. 
The Advanced Stirling Engine Systems Development Project involves generic research on critical Stirling engine components using existing and advanced technology. Tests and evaluations of these engines are conducted in government and industry facilities. Supporting Research and Technology activities are included in this project to provide technological options for the reduction of developmental risks.

The Vehicle Systems Project is designed to develop innovative and more efficient components for use in conventional vehicles. Present programs include the Gas Turbine Bus Program, the Turbocompound Diesel Program, the Truck Bottoming Cycle Program, the Diesel Emissions Control Technology Program, the Advanced Transmission Technology Program, the Controlled Speed Accessory Drive Program, and the Automatic Engine Shutoff and Restart System Program. The latter two programs already have been completed successfully and the Gas Turbine Bus Program and the Diesel Emissions Control Technology Program were terminated during FY 1981.

\section{Major Accomplishments}

The major Program accomplishments since publication of the Second Annual Report to Congress are as follows:

Advanced Gas Turbine (AGT) Engine Systems Development Project

- Completed system designs for advanced gas turbines for use in 5- and 6-passenger cars.

- Converted high-temperature $\left(2070^{\circ} \mathrm{F}\right)$ ceramic material into bladed turbine wheel, nozzle/shroud assembly and plenum, and demonstrated high-temperature operation in heavy duty gas turbine engines.
- Initiated engine simulation rig tests of a ceramic-bladed rotor assembly.

Advanced Stirling Engine (ASE) Systems Development Project

- Completed 1981 first generation (Mod I) component and engine system design on schedule and within cost allowance.

- Built and assembled two ASE Mod I engines and conducted preliminary tests, showing significant improvements in part load efficiency and steady-state emissions.

- Reduced Stirling engine heater tube hydrogen permeability by 90 percent, utilizing carbon monoxide - carbon dioxide dopant.

Vehicle Systems Project

- Completed 54,000-mile road test of a prototype heavy-duty turbo-compound engine, showing 4 to 5 percent improvement in fuel economy.

- Initiated feasibility study for a light-duty adiabatic diesel engine.

- Completed integration of five gas turbine propulsion systems in advanced design urban buses, and initiated revenue service in Baltimore, Maryland; completed integration of four gas turbine propulsion systems in inter-city buses, and initiated revenue service with Greyhound Lines, Inc.

\section{Recommendations}

Based on experience gained to date, the requirements placed on DOE by Title III of Public Law 95238, DOE's assessment of progress toward the overall program objectives, and uncertainties regarding future appropriations, there are no recommendations at this time pertaining to additional R\&D programs or new legislation. 


\section{Introduction and Overview}

The Automotive Propulsion Research and Development Act of 1978 focused on advancing the technology of automotive propulsion systems. In formulating the Act, Congress found that:

- Existing automobiles do not meet the $\mathrm{Na}$ tion's long-term environmental and energy goals.

- Insufficient resources are being devoted to research and development (R\&D) on advanced automobile propulsion systems.

- With sufficient R\&D, alternatives to existing systems could meet long-term goals at reasonable cost.

- Expanded R\&D would complement and stimulate corresponding private sector efforts.

Because of the Nation's energy problems, Congress felt that advanced automobile propulsion system technology should be developed quickly. Through the Act, Congress expressed its intent for the Department of Energy (DOE) to:

- Make R\&D contracts and grants for development of advanced automobile propulsion systems with in five years, or within the shortest practicable time consistent with appropriate R\&D techniques.

- Evaluate and disseminate information about advanced automobile propulsion system technology.

- Preserve, enhance, and facilitate competition in R\&D of existing and alternative automotive propulsion systems.

- Supplement, but neither supplant nor duplicate, private industry $R \& D$ efforts.
Implementation of the Act is the responsibility of the Office of Vehicle and Engine R\&D of DOE. The Lewis Research Center (LeRC) of the National Aeronautics and Space Administration (NASA) is the Technical Project Manager and is responsible for accomplishing project objectives. Specific program objectives have been established by DOE to demonstrate improvements in engine efficiency and achievement of multifuel capability by 1985 .

Since the inception of the first Federal government-supported heat engine program in 1971, a continuous reduction of the number of systems under development has been an integral part of the program strategy. Of the engines considered, only the gas turbine and Stirling engines have survived the development criteria. The R\&D programs in progress address the high risk technical problems of these two engine types, which must be solved if either of these engines is to replace the conventional spark ignition or diesel engines.

In February 1981, the Administration proposed to rescind $\$ 26.5$ million from the original FY 1981 appropriations of $\$ 67.9$ million for vehicle propulsion R\&D. These rescissions were consistent with the proposed termination of all commercialization and market research activities, curtailment of vehicle demonstration tests, and reduction in scope of all advanced heat engine development projects. Subsequently, Congress restored $\$ 6.1$ million to continue the advanced heat engine development efforts at the proof-of-concept level. 


\section{Status of Conventional Powertrain Technology}

Automotive propulsion system technology is changing rapidly due to the rising price of fuel and increasingly stringent environmental and safety standards. Although the number of diesel-powered automobiles is rapidly increasing, the uniform charge spark ignition Otto cycle engine will predominate in the near- to mid-term. The automotive industry is heavily committed to this engine and is conducting technology development aimed at further improvement of the Otto engine and, to a lesser extent, the diesel. Therefore, participation of the government in Otto and diesel engine R\&D is in general not required.

Other areas of the vehicle and its powertrain are also undergoing intensive development to improve fuel economy, including the reduction of vehicle weight, size, aerodynamic drag, and rolling resistance, engine weight, and engine displacement, and the use of improved transmissions and emission control systems.

Uniform Charge Otto Engines: Fuel economy gains have resulted primarily from vehicle downsizing and the growing consumer preference for small cars. To meet the Corporate Average Fuel Economy and emission requirements through 1985 and subsequent model years, the auto manufacturers will rely heavily on (1) friction reduction, (2) improved combustion, (3) improved accessories and auxiliaries, (4) smaller displacement engines with turbochargers or superchargers, (5) increased compression ratio, and (6) advanced microprocessor control of key engine parameters.

Another promising technique involves the incorporation of engine modifications for operation on alcohol (methanol) fuels. 'Research on methanol engines has been conducted by DOE and industry. and efficiency improvements of 15 percent have been achieved relative to equivalent gasoline engines. Currently, DOE's Office of Alcohol Fuels is investigating the potential for further efficiency improvements by dissociation of methanol into carbon monoxide and hydrogen on-board the vehicle. This approach makes use of exhaust waste heat and increases the heating value of the dissociation products by as "much as 20 percent relative to methanol.

Stratified Charge Otto Engines: Of the many configurations possible, two designs are of current interest. Honda's divided chamber Compound Vortex Controlled Combustion (CVCC) engine is presently in production and is marketed in the United States. Stili in the development stage is Texaco's Controlled Combustion System (TCCS) open chamber engine, which utilizes direct cylinder fuel injection in place of carburetion. The development of another open chamber engine, the Ford PROCO, was terminated by Ford in 1980.

Rotary Engines: The Wankel design is the only rotary engine configuration presently in production. It is attractive because of its simplicity, high powerto-weight ratio, and inherently low oxides of nitrogen $\left(N_{x}\right)$ emissions. Principal disadvantages are low fuel economy and high hydrocarbon (HC) and carbon monoxide (CO) emissions. Toyo Kogyo and Audi-NSU have marketed production models, and many other organizations have conducted development work in the past. The market share of the rotary engine is not expected to increase significantly in the near-to midterm.

Diesel Engines: Diesel automobiles show a 30 to 50 percent higher fuel economy than their spark ignition counterparts while meeting current emission regulations. A number of manufacturers are now pursuing the development of direct-injection diesel engines for automobiles because of the marked fuel ecunonly advantage of this engine type relative to the indirect-injection diesels now in use. Diesel engines emit relatively low levels of $\mathrm{HC}$ and $\mathrm{CO}$, but produce particulates and a number of presently unregulated pollutants. The particulates are of special concern, because of their potential carcinogenic nature. Research efforts in progress are aimed at the development of viable particulate and NOx control techniques, and the evaluation of health effects of diesel emissions.

Transmissions: Transmission configurations under development include automatic units with overdrive, four speeds, torque converter lockup clutch, torquesplit capability, and continuously variable transmissions. Versions of all, except the latter, are now in production. Borg-Warner is expected to begin production of a continuously variable transmission for automobiles in 1983.

Accessory Drives: More efficient accessory drives, operating at near-constant speed, have been developed by several companies. These drives are expected to be introduced by the automobile companies beginning, with the $1983 / 1984$ models. 


\section{Automotive Technology Development Program}

Title III of Public Law 95-238 is entitled "Automotive Propulsion Research and Development Act of 1978," and mandates that the Secretary of Energy undertake "expanded research and development of new automotive propulsion systems." Prior government programs identified the gas turbine and Stirling engines as the highest potential candidates for continued development, and these are the focus of the Automotive Technology Development (ATD) Program.

The following material reflects plans, adjusted for FY 1981 budget rescissions resulting in the termination of all commercialization, market research, and vehicle demonstration projects.

\subsection{Project Requirements and Objectives}

The Advanced Gas Turbine (AGT) Engine Systems Development Project, and the Advanced Stirling Engine (ASE) Systems Development Project satisfy the requirements of Title III of Public Law 95238, which direct the DOE to:

- Develop advanced automotive propulsion systems as soon as practicable, giving priority to fuel-flexible systems.

- Identify related basic research needs.

- Supplement, but not supplant or duplicate, private sector efforts.

The overall objectives of the AGT and ASE Projects are as follows:

- Improve fuel economy at least $\mathbf{3 0}$ percent over equivalent gasoline-powered conventional vehicles.

- Meet all 1985 Federal emissions standards, including those for particulates, and meet the $0.4 \mathrm{~g} / \mathrm{mi} \mathrm{NO}$. research goal.

- Be compatible with alternative fuels.

- Be ready for production in the 1990 s.

\subsection{Advanced Gas Turbine Engine Systems Development Project}

The gas turbine engine has been used for about three decades in aircraft and industrial applications, and has reached a high state of development. The principal advantages of the gas turbine include potentially excellent fuel economy and emissions, multifuel capability, good torque characteristics, potentially high reliability and durability, low maintenance, compactness, and light weight. The main dis- advantages of past automotive gas turbines have been high manufacturing cost, high fuel consumption at idle and at low power, and slow throttle response.

Automotive gas turbine engines have been under investigation by the major auto companies since the early 1950s. In the mid-1960s, Chrysler loaned 50 turbine-powered automobiles to selected consumers for evaluation. In general, the users were impressed by the engine's smoothness, reliable cold start characteristics, and projected low maintenance, but objected to its low fuel economy and noticeable hesitation during acceleration from a standstill.

\section{Technical Plan}

The AGT Engine Systems Development Project is intended to alleviate the known shortcomings of gas turbine engines relative to conventional piston engines. Implementation is through joint efforts between industry and government. This is expected to encourage the industry to eventually begin preproduction engineering on its own. The project has three major technical elements:

- Engine Development

- Supporting Research and Technology

- Early Technology Application

The approach of the AGT Engine Systems Development Project is to use the gas turbine experience of the auto industry, to add aerospace knowhow and components, and to develop ceramic materials to achieve improved AGT fuel economy. Systems development is being carried out through cost sharing contracts with two industry teams-Garrett Corporation/Ford Motor Company, and Detroit Diesel Allison (DDA)/Pontiac Motor Divisions of General Motors Corporation. The Garrett/Ford design uses a single shaft, while the General Motors design employs the two-shaft concept. The two engines are regenerated, and both require hot section ceramic components to achieve the fuel consumption goals. Mock-ups of the Garrett and General Motors engines are shown in Figures 3-1 and 3-2, respectively.

Supporting Research and Technology efforts are concerned with improving fuel consumption and manufacturing cost of key engine components. Projects include the development of high-temperature ceramic materials, low-emission combustors, advanced turbomachinery concepts, and improved systems analysis. Major emphasis is placed on the de- 


\section{AGT101 POWERTRAIN}



Figure 3-1. Mock-up of Garrett/Ford AGT Powertrain



Figure 3-2. Mock-up of General Motors AGT Installation 
velopment of ceramic materials to allow the high working temperatures necessary in order for the fuel economy goals to be met.

A number of researchers are presently working under contracts and grants to DOE and NASA. Garrett is in the process of establishing the effects on ceramic materials of long-term exposure to typical turbine engine environments. Ford and NASA are working in the area of higher strength silicon nitrides. Ford is testing ceramic turbine stators fabricated by several vendors, and NASA is involved in combustion studies and combustor testing. Garrett and NASA are investigating basic design technology for small highperformance turbomachinery, and NASA is conducting system analysis work to permit independent assessments of AGT system alternatives.

Early Technology Application is aimed at nearterm demonstration of improvements in component technology, so that in-service problems are identified early in the development process. Two by-products of this project are earlier use of the technology in nonpassenger car applications, e.g., trucks, and vehicle verification of predicted state-of-the-art behavior. As part of this project, General Motors is incorporating ceramic components and other near-term technology into the existing General Motors heavyduty gas turbine engine, and ultimately operational experience will be gained on the highway. The remainder of the effort involves ongoing support of existing test bed engines and test vehicles.

\section{Technology Status}

Analysis results show a $42 \mathrm{mpg}$ projected fuel economy over the EPA city/highway driving cycle for an $85 \mathrm{hp}$ AGT-equipped $3000 \mathrm{lb}$ vehicle operated on. diesel fuel. Based on scaling analyses, a $2000 \mathrm{lb}$ vehicle, equipped with a $50 \mathrm{hp}$ AGT engine, delivers a city/highway fuel economy of $54 \mathrm{mpg}$ on diesel fuel. This is 20 percent higher than projected for a comparable conventional spark ignition vehicle. The partload efficiency goals on which these projections are based and data obtained from rig tests are as follows:

8.

Component
Compressor
Compressor Turbine
Power Turbine

Component modifications required to achieve the fuel economy goal include the use of ceramics in the engine hot section, redesign of compressor and turbine blading, and reduction of heat exchanger leakage.

Technology for use of ceramics in gas turbines is advancing. Efforts center on sintered silicon nitride
$\left(\mathrm{Si}_{3} \mathrm{~N}_{4}\right)$ and silicon carbide $(\mathrm{SiC})$ as the turbine rotor material. Non-destructive evaluation and proof test procedures for components have progressed, and long-term tests are underway to further define component life.

\section{Environmental Consideration}

The goals of the AGT Project include environmental acceptability and operational safety. They address the principal concerns of the Transportation Energy Conservation Environmental Development Plan, 1979 Update. The objectives of the AGT Project are to meet or surpass future Federal and State emissions and noise regulations, and to meet $\mathrm{Na-}$ tional Environmental Policy Act (NEPA) requirements. Any potential hazards associated with turbine wheel failure are to be mitigated, and potential occupational health effects, if any, resulting from manufacturing are to be assessed.

\section{Project Schedule}

The AGT Project schedules and major milestones are presented in Figure 3-3. The project is being restructured following determination by Congress of appropriation levels for FY 1982.

\section{Major Project Accomplishments}

The major project accomplishments since publication of the Second Annual Report to Congress are as follows:

- Completed system designs for advanced gas turbines for use in 5- and 6-passenger cars.

- Converted high temperature $\left(2070^{\circ} \mathrm{F}\right) \mathrm{ce}-$ ramic material into a bladed turbine wheel, nozzle/shroud assembly and plenum, and demonstrated high-temperature operation in heavy-duty gas turbine engines.

- Continued component tests and development for the General Motors and Garrett/Ford AGT with satisfactory progress.

- Achieved 102 percent of design speed before failure with an alpha SiC-bladed turbine rotor.

- Verified feasibility of hot isostatic pressing technique to increase strength of sintered alpha silicon carbide.

- Completed evaluation of ceramics for stator applications.

- Initiated engine simulation rig tests of a ceramic-bladed rotor assembly. 


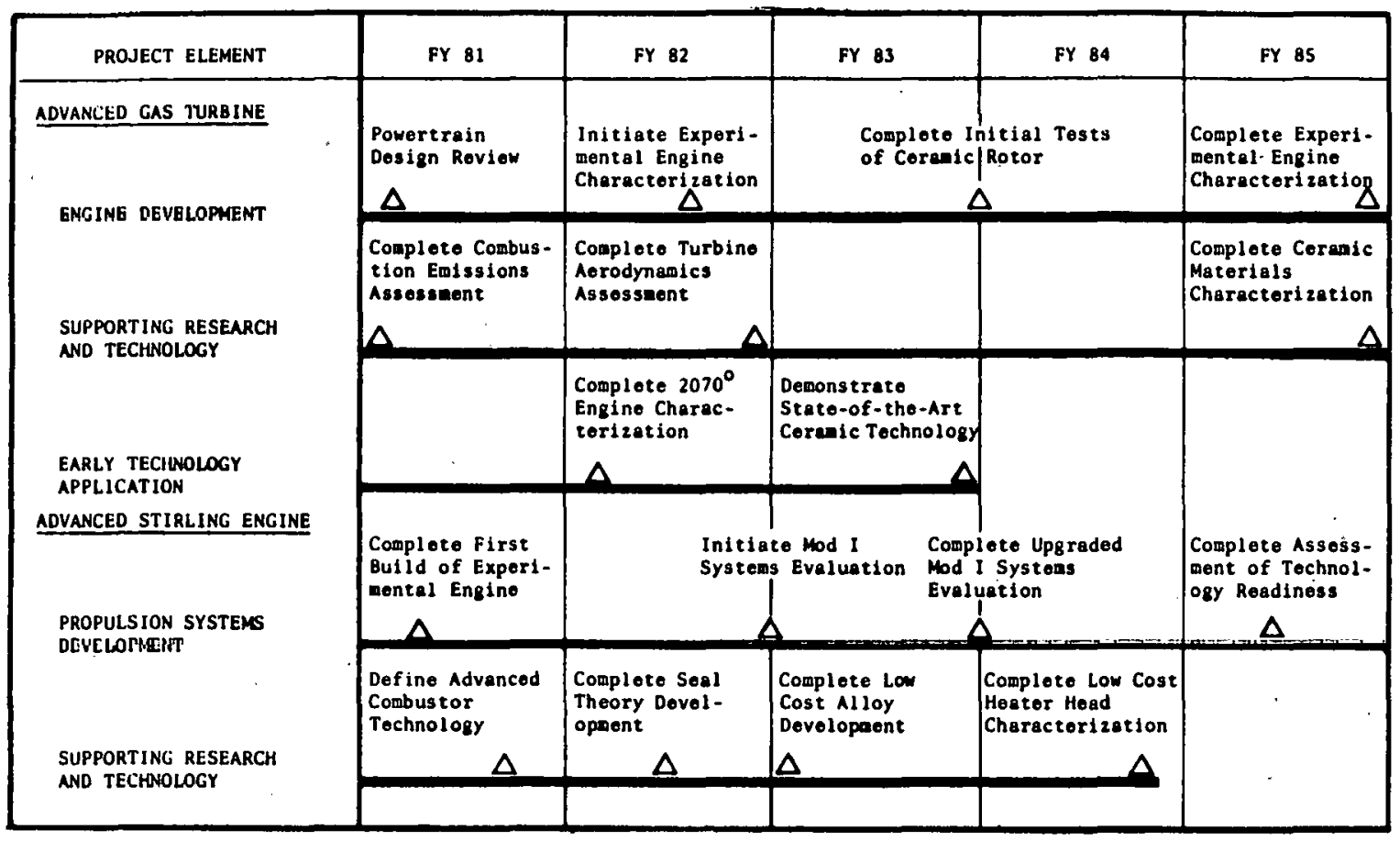

Figure 3-3. Advanced Gas Turbine and Stirling Engine Systems Development Project Schedules

\subsection{Advanced Stirling Engine Systems Develop- ment Project}

The Advanced Stirling Engine (ASE) is a closedcycle machine which converts thermal energy to mechanical work by alternately compressing and expanding a confined working gas, usually hydrogen, with controlled heat addition and rejection. Interest in the engine for automotive use stems from its potential for high fuel economy and low exhaust emissions. Other advantages include multifuel capability and good torque characteristics. However, the seal and control system technology areas require further development, and engine cost and durability have not yet been fully assessed.

The basic technology for the Stirling engine is well established. Laboratory engines have been operated for thousands of hours, and design techniques are well known. Most of the Stirling engine development work conducted since the 1950s has involved the N.V. Philips Company of the Netherlands, either directly or through licensing agreements. Starting in 1975, Ford Motor Company was funded by the Energy Research and Development Administration to perform the preliminary design of a Stirling engine for compact cars, and to develop an advanced automotive engine. In 1978, Ford elected to terminate the program and to accelerate the development of its PROCO stratified charge engine by re-directing its limited research resources. United Stirling of Sweden has been involved in automotive Stirling work for a number of years, and has installed engines in a Ford Pinto and a European Ford Taunus.

\section{Technical Plan}

The ASE Project is intended to follow a system- atic evolutionary approach. System development is carried out by a team consisting of Mechanical Technology, Incorporated (MTI) as the prime contractor, and United Stirling and AM General as subcontractors. The ASE Project has two major parts: Advanced Stirling Propulsion Systems Development, and Supporting Reisearch and Technology.

The objective of the ASE Propulsion Systems Development Project is to advance the state of the art through the development and testing of improved engine components. Project logic is based on the development and use of successive generations of Stirling engines. The baseline engine is the existing United Stirling P-40 engine. The ASE Mod I is the first generation automotive engine, which serves as the focal point for guiding component, subsystem, and system development efforts. The principal design objective is to improve part-load efficiency and power relative to weight and volume, and to provide a technology base for the ASE Mod II. The principal objective of the Mod II is to improve engine efficiency by increasing operating temperature from $720^{\circ} \mathrm{C}$ in Mod 1 to $820^{\circ} \mathrm{C}$. The $\mathrm{P}-40$ engine, installed in an American Motors Spirit automobile, is shown in Figure 3-4.

Supporting Research and Technology is designed to provide technological options which reduce the risks in meeting project objectives. These include:

- Seals: Development of piston rod seals to retain the high-pressure hydrogen working gas and to prevent oil contamination.

- Materials: Emphasis on hydrogen containment and low-cost alloys.

- Controls: Achievement of more efficient and reliable engine power controls.

- Small Engine Experiments: Conduct of com- 
ponent development tests to validate computer simulation models.

- Combustors: Development of low-emissions combustion technology through more uniform temperature and fuel distribution.
- Systems Analysis: Verification of NASAgenerated Stirling engine computer models, and assessment of the fuel economy potential of Stirling vehicles.

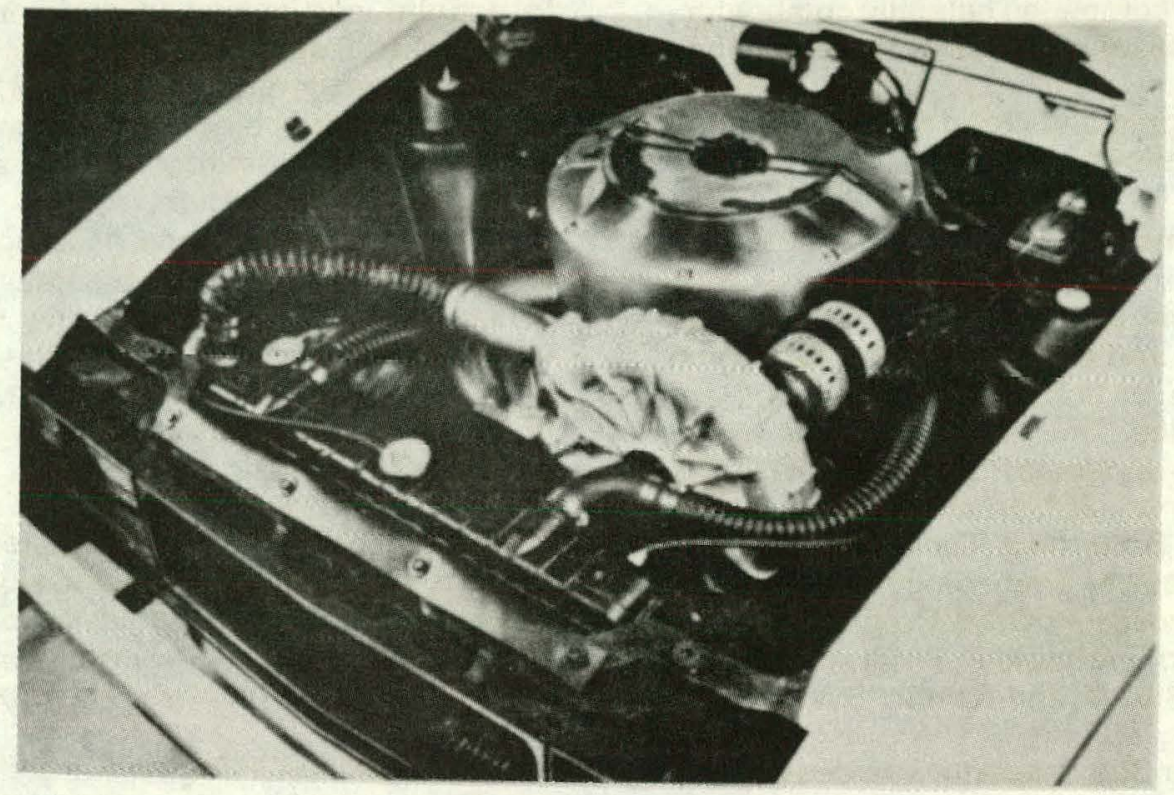

Figure 3-4. Stirling Engine Installation in an American Motors Spirit Automobile

\section{Technology Status}

Based on an ASE efficiency goal of 37.7 percent at the average operating point (AOP), the fuel economy of a Mod II-equipped $3000 \mathrm{lb}$ automobile over the EPA city/highway cycle is projected to be 41.1 mpg on diesel fuel. This is 52 percent higher than the $27 \mathrm{mpg}$ projected by General Motors for an equivalent 1984 model year conventional spark ignition vehicle. To date an AOP engine efficiency of 31.4 percent has been demonstrated with Mod I, which is a significant improvement over the 17 to 21 percent efficiency of the baseline P-40 engine. The additional improvement in engine efficiency that is required to achieve the fuel economy goal is expected to be attained by ( 1 ) use of higher heater head temperatures, (2) part-load optimization of specific engine components, (3) reduction in seal friction and heat transfer losses, (4) reduction of auxiliary power requirements, (5) improvements in combustor aerodynamics, and (6) transmission optimization. Stirling engines have already met the 1983 Federal emission standards, and further reductions in emissions are considered to be feasible. The principal technological challenges facing the Stirling engine are related to its size, weight, and cost, all of which must be reduced to make the engine more attractive for automobile applications.

\section{Environmental Considerations}

The goals of the ASE Project include environmental acceptability and operational safety. The objectives are to meet or surpass future Federal and State emissions and noise regulations, and to meet NEPA requirements. Meeting the 1985 emissions standards is not expected to be a problem, but additional testing, including particulates, is needed.

\section{Project Schedule}

The ASE Project schedule and major milestones are presented in Figure 3-3. The project is being restructured following determination by Congress of appropriation levels for FY 1982.

\section{Major Project Accumplishments}

The major project accomplishments since publication of the Second Annual Report to Congress are as follows:

- Completed 1981 ASE Mod I component and engine system design on schedule and within cost allowances.

- Built two ASE Mod I engines, and conducted preliminary tests showing significant im- 
provements in fuel economy and steadystate emissions.

- Developed a new piston ring seal, delivering 3 to 6 percentage points higher engine efficiency.

- Completed Mod I cooling tests. mi

- Identified improved heater tube materials, and reduced hydrogen permeability by 90 percent using $\mathrm{CO}-\mathrm{CO}_{2}$ dopant.

- Successfully completed catalytic combustorheater head testing, with very low emissions measured.

- Completed aging and creep tests for group II commercial alloys.

\subsection{Vehicle Systems Project}

The Vehicle Systems Project is designed to develop additional new and efficient vehicle and engine components for use in both conventional and advanced future vehicles. The seven programs which are part of the Vehicle Systems Project are the (1) Gas Turbine Bus Program, (2) Turbocompound Diesel Program, (3) Truck Bottoming Cycle Program, (4) Diesel Emissions Control Technology Program, (5) Controlled Speed Accessory Drive Program, (6) Advanced Transmission Technology Program, and (7) Automatic Engine Shutoff and Restart System Program.

The Gas Turbine Bus Program was designed to obtain operational data on a prototype heavy-duty gas turbine system under actual service conditions. Four Greyhound buses were equipped with DOEprovided gas turbine engines and operated in intercity revenue service. In cooperation with the Urban Mass Transportation Administration, four intra-city buses were also equipped with gas turbine propulsion systems and operated in revenue service in the city of Baltimore. Although the results of these demonstrations confirmed some of the advantages of the gas turbine, they also identified specific problem areas to be addressed by industry during the development of a mature engine and supporting infrastructure. The program was terminated in FY 1981 and the resulting data are being made available to engine manufacturers and bus operators for use in future improvement programs.

The Turbocompound Diesel Program was designed to evaluate a turbocompound technology under development by the Cummins Engine Company. Turbocompounding extracts extra work from hot exhaust gas, thereby improving fuel economy. Road tests covering 54,000 miles have shown a 4 to 5 percent improvement in fuel economy compared with a direct-injection diesel. The system, once proven, will be used on the "adiabatic" engine under development at Cummins with U.S. Army funding. Application of the adiabatic concept to automobile engines is also being investigated.

The Truck Bottoming Cycle Program being conducted by the Thermo Electron Corporation is intended to develop and test a waste heat utilization system for trucks. The system uses exhaust gas to boil an organic fluid, which then powers a turbine geared to the driveshaft. Road tests conducted to date show fuel savings of about 10 percent, with 15 percent projected after component modifications.

The Diesel Emissions Control Technology Program was conducted to provide a state-of-the-art survey of light-duty diesel engine developments in the world, including emission control concepts, and to acquire particulate samples from current production diesel engines for health impact studies. The program was terminated in FY 1981, and the particulate samples are being delivered to the Office of Environmental Protection, Safety, and Energy Preparedness for evaluation.

The Controlled Speed Accessory Drive Program is designed to measure fuel economy benefits of advanced accessory drives, using government pool vehicles in service. A fuel economy gain of 6 percent was demonstrated. The program was completed during FY 1981 and the results were made available to industry.

The Advanced Transmissions Technology Program is intended to enhance the technology base for advanced automotive transmissions. Present activities involve test and analysis of a traction-drive speed reducer by NASA, and basic research in the area of traction contact phenomena by Transmission Research, Inc.

The Automatic Engine Shutoff and Restart System Program was conducted to verify improvements in fuel economy and emissions resulting from fuel shutoff during idle and deceleration. The concept has gained acceptance by some automobile manufacturers and the DOE-sponsored program has been completed.

\section{Major Project Accomplishments}

The major Project accomplishments since publication of the Second Annual Report to Congress are as follows:

- Completed integration of five turbine propulsion systems in advanced design urban buses and initiated revenue service in Baltimore, Maryland; completed integration of four gas turbine propulsion systems in inter-city buses and initiated revenue service with Greyhound Lines, Inc.

- Completed 54,000-mile road test of a prototype heavy-duty turbocompound engine, showing 4 to 5 percent improvement in fuel economy.

- Initiated feasibility study for a light-duty adiabatic diesel engine.

- Completed second annual state-of-the-art report on light-duty diesel engines.

- Completed Controlled Speed Accessory Drive demonstration program.

- Completed Automatic Engine Shutoff and Restart System evaluation program.

- Initiated traction-drive fatigue life tests. 


\section{Management Plan and Policy Transition}

Execution of the Automotive Technology Development Program is being carried out within DOE's Technology Development and Analysis Division, Office of Vehicle and Engine R\&D. As the organization responsible for program management, this division formulates and manages automotive research and development projects, and interacts with industry at the appropriate levels for projects directed toward energy conservation within the highway vehicle sector (Figure 4-1).

DOE and NASA are working under an interagency Agreement and a Memorandum of Understanding. The Lewis Research Center (LeRC) of NASA has been designated as Technical Project Manager for these projects. Based on funding guidelines provided by DOE, NASA LeRC performs project management functions in accordance with LeRC organizational procedures. LeRC is responsible for accomplishing project technical objectives, developing detailed project technical plans, integrating technology disciplines within the project, conducting the procurement process, interacting with the auto industry, and solving contractual and technical problems.

Approximately 90 percent of the project funds are allocated through LeRC to industry, universities, and individuals for work on technical project elements. Approximately 10 percent of the project funds are used to support LeRC in-house research, testing, and project management functions.

Monthly reviews are held between the DOE Program Office and the LeRC Technical Project Office to coordinate project status in the areas of funding and technical accomplishments. In addition, to enhance communication among DOE/NASA, industry, and the public, annual Contractors Coordination Meetings are held on the technical aspects of various elements of this Program.

In February 1981, the Administration proposed to rescind $\$ 26.5$ million from the original FY 1981 appropriations of $\$ 67.9$ million for vehicle propulsion R\&D. These restrictions were consistent with the proposed termination of all commercialization and market research activities, curtailment of vehicle demonstration tests, and reduction in scope of all advanced heat engine development projects. Subsequently, Congress restored $\$ 6.1$ million to continue the advanced heat engine development efforts at the proof-of-concept level.

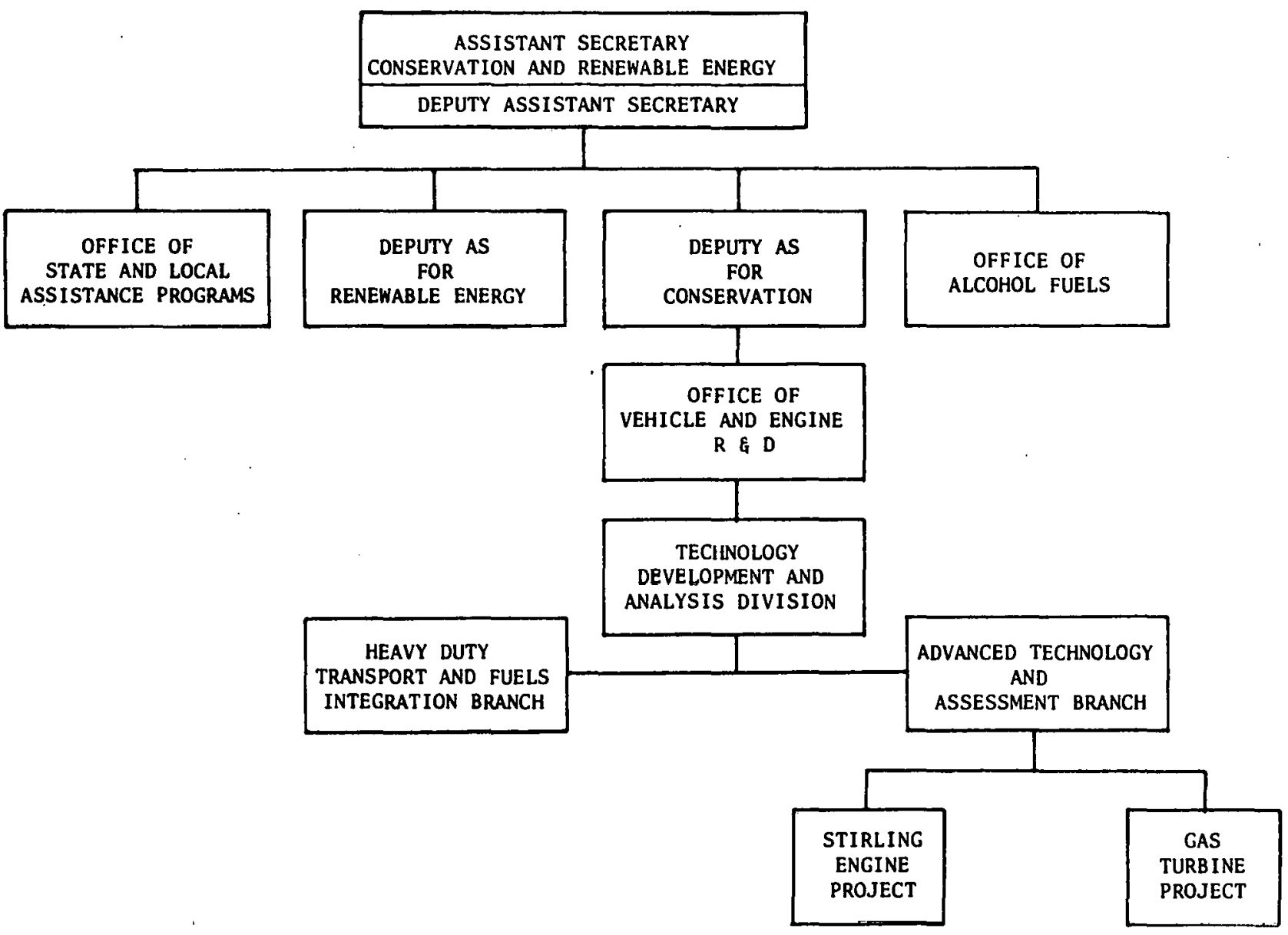

Figure 4-1. DOE Organization for ATD 


\section{Recommendations}

Based on experience gained to date, the requirements placed on DOE by Title III of Public Law 95-238, DOE's assessment of progress toward the overall program objectives, and the uncertainties regarding further budget appropriations, there are no recommendations at this time pertaining to additional R\&D programs or new legislation. 


\section{Appendices}

Contract and grant procurement information for ongoing contracts and new contract awards made since the enactment of Title III of Public Law 95-238 on 25 February 1978 is summarized in Appendices A, B, C, and D. Each. Appendix lists all contracted efforts, including cost sharing contracts, contract start dates, and actual or projected completion dates. These Appendices are provided to satisfy Sections 310(a), (3) and 304(f), (4) of Public Law 95-238.

\subsection{Appendix A - Procurement Summary- Advanced Gas Turbine Engine Systems Development Project}

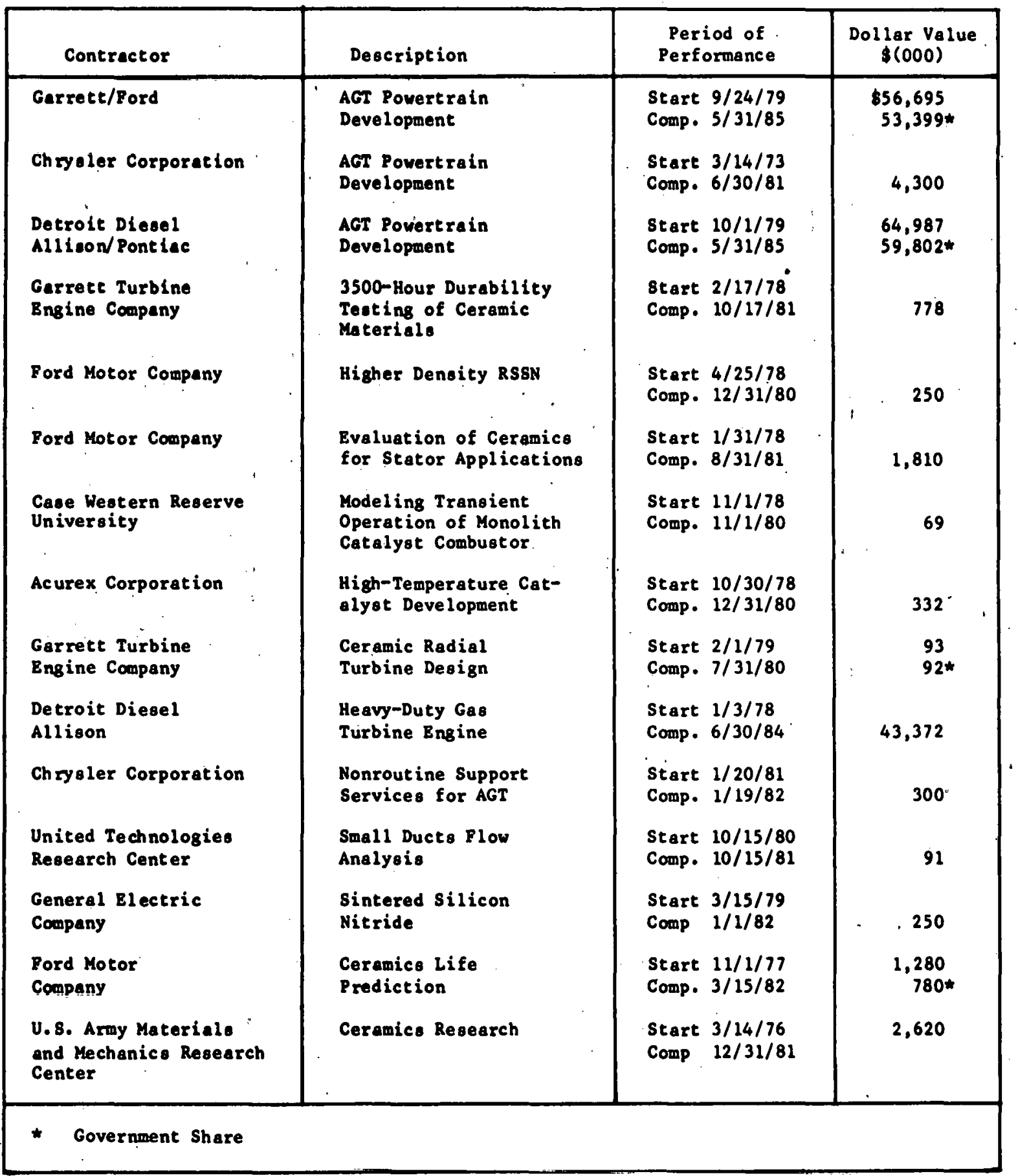




\subsection{Appendix B - Procurement Summary- Advanced Stirling Engine Systems \\ Development Project}

\begin{tabular}{|c|c|c|c|}
\hline Contractor & Description & $\begin{array}{l}\text { Period of } \\
\text { Performance }\end{array}$ & $\begin{array}{l}\text { Dollar Value } \\
\quad \$(000)\end{array}$ \\
\hline MTI/United Stirling/AMG & $\begin{array}{l}\text { Improved Engine } \\
\text { Development }\end{array}$ & $\begin{array}{l}\text { Start } 3 / 78 \\
\text { Comp. } 11 / 84\end{array}$ & $\$ 89,498$ \\
\hline ERG, Inc. & $\begin{array}{l}\text { Advanced Stirling Engine } \\
\text { Cooler Regenerator }\end{array}$ & $\begin{array}{l}\text { Start } 9 / 79 \\
\text { Comp. } 2 / 80\end{array}$ & 54 \\
\hline $\begin{array}{l}\text { Mechanical Tech- } \\
\text { nology Inc. }\end{array}$ & $\begin{array}{l}\text { Evaluation of Hydrodynamic } \\
\text { Oil Pumping Ring Seals }\end{array}$ & $\begin{array}{l}\text { Start } 6 / 79 \\
\text { Comp. } 12 / 80\end{array}$ & 117 \\
\hline University of Toledo & $\begin{array}{l}\text { Analysis of Stirling } \\
\text { Oil-Pumping Ring Seal }\end{array}$ & $\begin{array}{l}\text { Start } 7 / 77 \\
\text { Comp. } 7 / 78\end{array}$ & 22 \\
\hline Boeing Company & $\begin{array}{l}\text { Reciprocating Seals } \\
\text { for Stirling Engine }\end{array}$ & $\begin{array}{l}\text { Start } 4 / 77 \\
\text { Comp. } 8 / 79\end{array}$ & 124 \\
\hline Shaker Research & Elastomeric Seals & $\begin{array}{l}\text { Start } 1 / 78 \\
\text { Comp. } 6 / 80\end{array}$ & 153 \\
\hline Carnegie-Mellon & Seal Heat Transfer & $\begin{array}{l}\text { Start } 7 / 78 \\
\text { Comp. } 11 / 80\end{array}$ & 153 \\
\hline IITRI & $\begin{array}{l}\text { Hydrogen Permeability } \\
\text { Study }\end{array}$ & $\begin{array}{l}\text { Start } 9 / 77 \\
\text { Comp. } 9 / 80\end{array}$ & 194 \\
\hline $\begin{array}{l}\text { United Technology } \\
\text { Corporation }\end{array}$ & $\begin{array}{l}\text { Identification of a } \\
\text { Non-Strategic Cast Iron } \\
\text { Alloy for Stirling } \\
\text { Applications }\end{array}$ & $\begin{array}{l}\text { Start } 7 / 81 \\
\text { Comp. } 7 / 82\end{array}$ & 151 \\
\hline I ITRI & $\begin{array}{l}\text { Creep Rupture Behavior } \\
\text { of Iron Superalloys in } \\
\text { High Pressure Hydrogen }\end{array}$ & $\begin{array}{l}\text { Start } 9 / 79 \\
\text { Comp. } 3 / 81\end{array}$ & 316 \\
\hline University of Washington & $\begin{array}{l}\text { Design Manual for Stirling } \\
\text { Engine Second Edition }\end{array}$ & $\begin{array}{l}\text { Start } 5 / 78 \\
\text { Comp. } 10 / 79\end{array}$ & 52 \\
\hline $\begin{array}{l}\text { Pioneer Engineering and } \\
\text { Manufacturing Company }\end{array}$ & $\begin{array}{l}\text { Stirling Manufacturing } \\
\text { Cost Studies }\end{array}$ & $\begin{array}{l}\text { Start } 1 / 79 \\
\text { Comp. } 2 / 80\end{array}$ & $\begin{array}{l}52 \\
10^{*}\end{array}$ \\
\hline Rasor Associates Inc. & $\begin{array}{l}\text { Jet Impingement } \\
\text { System }\end{array}$ & $\begin{array}{l}\text { Start } 11 / 79 \\
\text { Comp. } 11 / 80\end{array}$ & 62 \\
\hline Acurex Corporation & $\begin{array}{l}\text { Computer Model/Catalytic } \\
\text { Combustor }\end{array}$ & $\begin{array}{l}\text { Start } 1 / 80 \\
\text { Comp. } 7 / 80\end{array}$ & 46 \\
\hline Martini Engineering & $\begin{array}{l}\text { Validate Stirling } \\
\text { Engine Control Program }\end{array}$ & $\begin{array}{l}\text { Start } 3 / 80 \\
\text { Comp. } 7 / 80\end{array}$ & 15 \\
\hline N.v. Philips & $\begin{array}{l}\text { Advanced Engine } \\
\text { Purchase }\end{array}$ & $\begin{array}{l}\text { Start } 6 / 80 \\
\text { Comp. } 8 / 80\end{array}$ & 200 \\
\hline $\begin{array}{l}\text { Mechanical } \\
\text { Technology Inc. }\end{array}$ & $\begin{array}{l}\text { Temperature Measure- } \\
\text { ment of Stirling Seals }\end{array}$ & $\begin{array}{l}\text { Start } 6 / 80 \\
\text { Comp. } 2 / 81\end{array}$ & 69 \\
\hline $\begin{array}{l}\text { AiResearch Casting } \\
\text { Company }\end{array}$ & $\begin{array}{l}\text { Cast Iron-base Cylinder } \\
\text { Regenerator Housing Alloy }\end{array}$ & $\begin{array}{l}\text { Start } 8 / 80 \\
\text { Comp: } / 11 / 82\end{array}$ & 491 \\
\hline * Stirling Project Share & & & . \\
\hline
\end{tabular}




\subsection{Appendix C - Procurement Summary- Vehicle Systems Project}

6.3. APPENDIX C - PROCUREMENT SUMMARY -VEHICLE SYSTEMS PROJEGT.

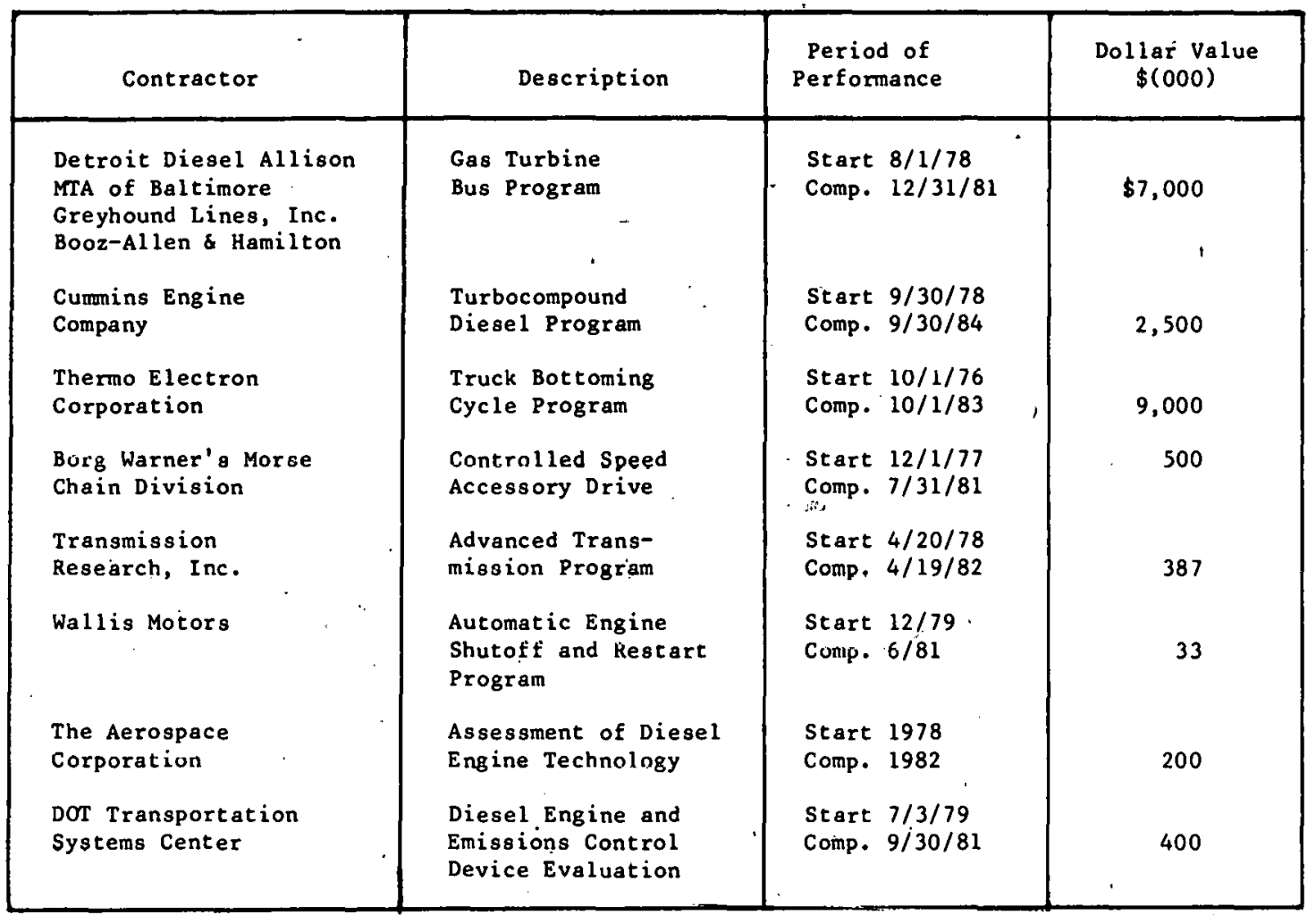




\subsection{Appendix D - Certification of New R\&D Contracts}

Section 304(f) of Title III of Public Law 95-238 requires that all new $R \& D$ funded under the authority of the Act supplements, but neither supplants nor duplicates, the automotive R\&D efforts of "private industry. To assure compliance with this requirement, the Secretary is required to issue administrative regulations specifying procedures, standards, and criteria for review and certification of each new R\&D contract, grant, DOE project, or projects of other Federal agencies (such as NASA-LeRC). These regulations were set forth at 10 CFR Part 473.

In order to consider the work offered by any applicant for possible support, the regulations require that the applicant submit, in addition to the normal RFP information required by DOE, form NASA-C-356 which provides specific information to justify certification in accordance with the regulation. A notice is then published in the Commerce Business Daily describing the nature of the proposal and inviting any interested person to submit a wriften objection. Following the close of the objection period, the manager makes an initial determination of compliance and submits appropriate proposals to the interagency review panel. The panel consists of representatives from DOE, NASA-LeRC, the Environmental Protection Agency, and the National Highway Traffic Safety Administration who are knowledgeable in the area of industry and Government R\&D on automotive propulsion. For each proposal, the panel makes a recommendation to the manager who then makes the final determination of compliance.

This procedure was followed for all R\&D contracts listed in Appendices A, B, and C which were initiated after the regulations took effect. No written objections were received as a result of the Commerce Business Daily notices, and certification was recommended by the interagency review panel for all of these new R\&D contracts. As a result of these regulations, the requirements of Section 304(f) have been satisfied. 
UNITED STATES

DEPARTMENT OF ENERGY

WASHINGTON, D.E.20585

OFFICIAL BUSINESS

PENALTY FOR PRIVATE USE, $\$ 300$
POSTAGE AND FFES PAID

U.S. DEPARTMENT OF ENERGY

DOE 350

nis?

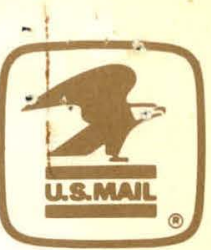

THIRD CLASS MAIL 